\title{
Activating mutations and senescence secretome: new insights into HER2 activation, drug sensitivity and metastatic progression
}

Swarnali Acharyya*

\begin{abstract}
HER2 amplification and overexpression is observed in approximately $20 \%$ of breast cancers and is strongly associated with poor prognosis and therapeutic responsiveness to HER2 targeted agents. A recent study by Bose and colleagues suggests that another subset of breast cancer patients without HER2 amplification but with activating HER2 mutation might also benefit from existing HER2-targeted agents and the authors functionally characterize these somatic mutations in experimental models. In a second study on HER2-driven breast cancer, Angelini and colleagues investigate how the constitutively active, truncated carboxy-terminal fragment of HER2, p95HER2, promotes metastatic progression through non-cellautonomous secretion of factors from senescent cells. These new findings advance our understanding of HER2 biology in the context of HER2 activation as well as offer new insights into our understanding of drug sensitivity and metastatic progression.
\end{abstract}

\section{Background}

One of the cancer biomarkers widely used today is the amplification and aberrant overexpression of human epidermal growth factor receptor (HER)2, a member of the ErbB family of receptor tyrosine kinases [1]. HER2 amplification/overexpression, observed in several cancers, including breast cancer, is associated with poor prognosis and predicts therapeutic benefit from anti-HER2 agents $[1,2]$. Trastuzumab, a monoclonal antibody, was the first agent targeting HER2 and was approved for the treatment of HER2 ${ }^{+}$breast cancer in 1998 [3]. Since then, several small molecule inhibitors targeting HER signaling have

\footnotetext{
*Correspondence: acharyys@mskcc.org

Cancer Biology and Genetics Program, Memorial Sloan-Kettering Cancer Center, 1275 York Avenue, New York, New York 10065, USA
}

been developed, such as the reversible HER1/HER2 inhibitor lapatinib and the irreversible pan-HER inhibitor neratinib $[4,5]$.

A major challenge in the treatment of HER2 ${ }^{+}$cancer is either intrinsic or acquired drug resistance. For example, many of the patients who respond initially to trastuzumab therapy often progress with time $[4,6]$. These challenges have now prompted promising clinical trials on combination therapies with multiple anti-HER agents and development of new therapies with alternative modes of HER2 blockade $[4,7,8]$. A second challenge in treating HER $2^{+}$breast cancers is the association of this aggressive subtype with metastatic progression, in particular, brain metastasis [9]. The ability of HER2 ${ }^{+}$cancer cells to colonize the brain coupled with the inability of antiHER2 agents to efficiently cross the blood brain barrier is thought to contribute to the development and progression of brain metastasis in HER2-positive cancers $[10,11]$. New insights into the mechanisms of HER2 therapy resistance and metastasis are urgently needed to improve the outcome for patients with HER2 ${ }^{+}$cancer. Recent studies shed light on two different aspects of HER2 biology with implications for drug sensitivity and tumor progression [12,13]. Bose and colleagues [13] address experimentally whether HER2 somatic mutations observed in patients activate HER2 and examine their sensitivity to existing anti-HER2 agents. Angelini and colleagues [12] explore how constitutive activation of the truncated carboxy-terminal fragment of HER2 known as p95HER2 promotes metastatic progression.

\section{Articles}

Bose and colleagues functionally characterize somatic mutations in the HER2 gene recently discovered in patients without HER2 amplification at an estimated mutation frequency of $1.6 \%$ [13-20]. Using in vitro kinase and cell growth assays as well as in vivo tumorigenesis models, the authors suggest that the majority of the HER2 somatic mutations analyzed are activating mutations and likely drivers of the HER2-dependent tumor progression. Bose and colleagues experimentally analyzed 
13 HER2 somatic mutations, out of which 7 (G309A in the extracellular domain and D769H, D769Y, V777L, P780ins, V842I and R896C in the kinase domain) were found to be activating [13]. The authors show that the HER2 somatic mutations represent a novel mechanism to activate HER2 that is alternative to the known HER2 amplification. Importantly, the authors test the efficacy of current HER2-targeted agents on these engineered HER2-mutant tumor lines. The best growth inhibition response was obtained with the irreversible HER2 inhibitor neratinib when compared to lapatinib or trastuzumab in these HER2 mutant cancer lines. This study has important biological and clinical implications. These findings suggest that a subset of breast cancer patients, such as those harboring HER2 somatic mutations, might benefit from HER2-targeted therapies even in the absence of HER2 amplification/overexpression. Moreover, the study also suggests that some HER2-targeted therapies might be more effective than others in treating HER2 mutated tumors, a finding that warrants further investigation.

The second study, by Angelini and colleagues, investigates how the constitutively active, carboxy-terminal fragment of HER2 known as 611-CTF or p95HER2 promotes metastatic progression [12]. 611-CTF or p95HER2 (referred to as p95HER2 hereafter) is expressed by a subgroup of HER2-positive breast cancers and is oncogenic in preclinical models [21]. Breast tumors expressing p95HER2 are often resistant to trastuzumab [22]. The authors show that forced expression of p95HER2 in an untransformed immortalized mammary epithelial cell line accelerates cell proliferation whereas p95HER2 expression in a breast cancer cell line results in marked proliferation arrest and senescence. Interestingly, the authors show that p95HER2 induces a relatively longlived secretome in senescent cells, which is composed of several growth factors, cytokines and proteases and requires HER2 signaling for its maintenance. Given the link between pro-inflammatory cytokine secretion associated with senescence and tumor progression [23], the authors test the possibility that the presence of p95HER2induced senescent cells in the primary tumor enhances distant metastasis. MCF7 breast cancer cells expressing Tet-regulated p95HER2 were injected subcutaneously and the p95HER2 gene was kept off until tumors had reached a predetermined size. On the one hand, induction of p95HER2 expression in the xenograft tumors indeed caused signs of senescence within the tumors but, on the other hand, increased the secretion of known protumorigenic factors from these senescent cells. In this context, the metastatic susceptibility of p95HER2-expressing mice was analyzed by injecting a second breast cancer cell line, MDA-MB-231, into these mice intracardially. Despite inducing senescence in primary tumor cells, the expression of p95HER2 resulted in significantly increased metastatic growth, potentially through the secretion of paracrine pro-metastatic factors from senescent cells [23]. The precise mechanisms by which p95HER2 promotes metastatic progression remains to be further elucidated.

\section{Viewpoint}

Through sequencing studies of cancer genomes, HER2 somatic mutations have been identified in breast, gastric and colorectal cancers [15]. Given the clinical relevance, Bose and colleagues reinforce the importance of phenotypic characterization of genetic alterations in experimental systems after their identification from genomic sequencing [13]. Furthermore, the study underscores the relevance of empirically testing the sensitivity of mutant tumors to multiple targeted agents as specific genetic alterations may dictate the tumor response to targeted therapy. The efficacy of multiple anti-HER agents remains to be examined in vivo, especially in the context of tumor progression and metastasis induced by HER2 mutant cancer cells.

It is known that carboxy-terminal fragments called p95HER2 are frequently found in HER2-expressing breast cancer cell lines and tumors and correlate with high metastatic spread [24]. Based on this clinical observation, the authors set out to explore the underlying mechanism and discovered that p95HER2 induced senescence in the tumor but paradoxically enhanced metastatic progression at the distant site [12]. The identity of such systemic factors associated specifically with p95HER2-induced senescence and their role in the promotion of metastasis remain to be determined. It is also currently unknown whether p95HER2 expression in tumors can promote brain metastasis specifically or increases overall metastatic burden. Furthermore, it will also be important to dissect the contribution of the immune system in inducing the senescence secretome and subsequent metastatic progression. Together, these two studies further our understanding of the alternative modes of HER2 activation, drug sensitivity and metastatic progression and have added importance in the age of genomic sequencing and targeted therapies for cancer.

\section{Abbreviations}

HER, human epidermal growth factor receptor.

\section{Competing interests \\ The author declares no competing interests.}

\section{Acknowledgements}

The author wishes to thank L Barrett, AK Biswas, D Chakravarty, E Comen, Z Granot, P Paik, T Oskarsson, S Vanharanta and RM White for insightful discussions. SA is supported by a K99 CA172697-01 grant from the National Cancer Institute.

Published: 23 April 2013 


\section{References}

1. Slamon DJ, Clark GM, Wong SG, Levin WJ, Ullrich A, McGuire WL: Human breast cancer: correlation of relapse and survival with amplification of the HER-2/neu oncogene. Science 1987, 235:177-182.

2. Moasser MM: The oncogene HER2: its signaling and transforming functions and its role in human cancer pathogenesis. Oncogene 2007 26:6469-6487.

3. Slamon DJ, Leyland-Jones B, Shak S, Fuchs H, Paton V, Bajamonde A, Fleming T, Eiermann W, Wolter J, Pegram M, Baselga J, Norton L: Use of chemotherapy plus a monoclonal antibody against HER2 for metastatic breast cancer that overexpresses HER2. N Engl J Med 2001, 344:783-792.

4. Stern HM: Improving treatment of HER2-positive cancers: opportunities and challenges. Sci Trans/Med 2012, 4:127rv2.

5. Pal SK, Pegram M: HER2 targeted therapy in breast cancer...beyond Herceptin. Rev Endocr Metab Disord 2007, 8:269-277.

6. Vogel CL, Cobleigh MA, Tripathy D, Gutheil JC, Harris LN, Fehrenbacher L, Slamon DJ, Murphy M, Novotny WF, Burchmore M, Shak S, Stewart SJ, Press M: Efficacy and safety of trastuzumab as a single agent in first-line treatment of HER2-overexpressing metastatic breast cancer. J Clin Oncol 2002, 20:719-726.

7. Scaltriti M, Verma C, Guzman M, Jimenez J, Parra JL, Pedersen K, Smith DJ, Landolfi S, Ramon y Cajal S, Arribas J, Baselga J: Lapatinib, a HER2 tyrosine kinase inhibitor, induces stabilization and accumulation of HER2 and potentiates trastuzumab-dependent cell cytotoxicity. Oncogene 2009, 28:803-814

8. Baselga J, Bradbury I, Eidtmann H, Di Cosimo S, de Azambuja E, Aura C, Gómez H, Dinh P, Fauria K, Van Dooren V, Aktan G, Goldhirsch A, Chang TW, Horváth Z, Coccia-Portugal M, Domont J, Tseng LM, Kunz G, Sohn JH, Semiglazov V, Lerzo G, Palacova M, Probachai V, Pusztai L, Untch M, Gelber RD, Piccart-Gebhart M; NeoALTTO Study Team: Lapatinib with trastuzumab for HER2-positive early breast cancer (NeoALTTO): a randomised, open-label, multicentre, phase 3 trial. Lancet 2012, 379:633-640.

9. Altaha $R$, Crowell $E$, Hobbs $G$, Higa G, Abraham J: Increased risk of brain metastases in patients with HER-2/neu-positive breast carcinoma. Cancer 2005, 103:442-443.

10. Eichler AF, Chung E, Kodack DP, Loeffler JS, Fukumura D, Jain RK: The biology of brain metastases-translation to new therapies. Nat Rev Clin Oncol 2011, 8:344-356.

11. Palmieri D, Bronder JL, Herring JM, Yoneda T, Weil RJ, Stark AM, Kurek R, VegaValle E, Feigenbaum L, Halverson D, Vortmeyer AO, Steinberg SM, Aldape K, Steeg PS: Her-2 overexpression increases the metastatic outgrowth of breast cancer cells in the brain. Cancer Res 2007, 67:4190-4198.

12. Angelini PD, Zacarias Fluck MF, Pedersen K, Parra-Palau JL, Guiu M, Bernadó Morales C, Vicario R, Luque-García A, Navalpotro NP, Giralt J, Canals F, Gomis RR, Tabernero J, Baselga J, Villanueva J, Arribas J: Constitutive HER2 signaling promotes breast cancer metastasis through cellular senescence. Cancer Res 2013, 73:450-458.

13. Bose R, Kavuri SM, Searleman AC, Shen W, Shen D, Koboldt DC, Monsey J, Goel N, Aronson AB, Li S, Ma CX, Ding L, Mardis ER, Ellis MJ: Activating HER2 mutations in HER2 gene amplification negative breast cancer. Cancer Discov 2013, 3:224-237.

14. Ellis MJ, Ding L, Shen D, Luo J, Suman VJ, Wallis JW, Van Tine BA, Hoog J, Goiffon RJ, Goldstein TC, Ng S, Lin L, Crowder R, Snider J, Ballman K, Weber J, Chen K, Koboldt DC, Kandoth C, Schierding WS, McMichael JF, Miller CA, Lu C, Harris CC, McLellan MD, Wendl MC, DeSchryver K, Allred DC, Esserman L,
Unzeitig G, et al:: Whole-genome analysis informs breast cancer response to aromatase inhibition. Nature 2012, 486:353-360.

15. Lee JW, Soung YH, Seo SH, Kim SY, Park CH, Wang YP, Park K, Nam SW, Park WS, Kim SH, Lee JY, Yoo NJ, Lee SH: Somatic mutations of ERBB2 kinase domain in gastric, colorectal, and breast carcinomas. Clin Cancer Res 2006, 12:57-61.

16. Shah SP, Morin RD, Khattra J, Prentice L, Pugh T, Burleigh A, Delaney A, Gelmon K, Guliany R, Senz J, Steidl C, Holt RA, Jones S, Sun M, Leung G, Moore R, Severson T, Taylor GA, Teschendorff AE, Tse K, Turashvili G, Varhol R, Warren RL, Watson P, Zhao Y, Caldas C, Huntsman D, Hirst M, Marra MA, Aparicio S: Mutational evolution in a lobular breast tumour profiled at single nucleotide resolution. Nature 2009, 461:809-813.

17. Kan Z, Jaiswal BS, Stinson J, Janakiraman V, Bhatt D, Stern HM, Yue P, Haverty PM, Bourgon R, Zheng J, Moorhead M, Chaudhuri S, Tomsho LP, Peters BA, Pujara K, Cordes S, Davis DP, Carlton VE, Yuan W, Li L, Wang W, Eigenbrot C, Kaminker JS, Eberhard DA, Waring P, Schuster SC, Modrusan Z, Zhang Z, Stokoe D, de Sauvage FJ, et al.: Diverse somatic mutation patterns and pathway alterations in human cancers. Nature 2010, 466:869-873.

18. Stephens PJ, Tarpey PS, Davies H, Van Loo P, Greenman C, Wedge DC, NikZainal S, Martin S, Varela I, Bignell GR, Yates LR, Papaemmanuil E, Beare D, Butler A, Cheverton A, Gamble J, Hinton J, Jia M, Jayakumar A, Jones D, Latimer C, Lau KW, McLaren S, McBride DJ, Menzies A, Mudie L, Raine K, Rad R, Chapman MS, Teague J, et al:: The landscape of cancer genes and mutational processes in breast cancer. Nature 2012, 486:400-404.

19. Banerji S, Cibulskis K, Rangel-Escareno C, Brown KK, Carter SL, Frederick AM, Lawrence MS, Sivachenko AY, Sougnez C, Zou L, Cortes ML, Fernandez-Lopez JC, Peng S, Ardlie KG, Auclair D, Bautista-Piña V, Duke F, Francis J, Jung J, Maffuz-Aziz A, Onofrio RC, Parkin M, Pho NH, Quintanar-Jurado V, Ramos AH, Rebollar-Vega R, Rodriguez-Cuevas S, Romero-Cordoba SL, Schumacher SE, Stransky N, et al:: Sequence analysis of mutations and translocations across breast cancer subtypes. Nature 2012, 486:405-409.

20. Comprehensive molecular portraits of human breast tumours. Nature 2012,490:61-70.

21. Pedersen K, Angelini PD, Laos S, Bach-Faig A, Cunningham MP, Ferrer-Ramón C, Luque-García A, García-Castillo J, Parra-Palau JL, Scaltriti M, Ramón y Cajal S, Baselga J, Arribas J: A naturally occurring HER2 carboxy-terminal fragment promotes mammary tumor growth and metastasis. Mol Cell Biol 2009, 29:3319-3331.

22. Scaltriti M, Rojo F, Ocaña A, Anido J, Guzman M, Cortes J, Di Cosimo S, Matias-Guiu X, Ramon y Cajal S, Arribas J, Baselga J: Expression of p95HER2, a truncated form of the HER2 receptor, and response to anti-HER2 therapies in breast cancer. J Natl Cancer Inst 2007, 99:628-638.

23. Davalos AR, Coppe JP, Campisi J, Desprez PY: Senescent cells as a source of inflammatory factors for tumor progression. Cancer Metastasis Rev 2010, 29:273-283.

24. Molina MA, Sáez R, Ramsey EE, Garcia-Barchino MJ, Rojo F, Evans AJ, Albanell J, Keenan EJ, Lluch A, García-Conde J, Baselga J, Clinton GM: NH(2)-terminal truncated HER-2 protein but not full-length receptor is associated with nodal metastasis in human breast cancer. Clin Cancer Res 2002, 8:347-353.

doi:10.1186/bcr3406

Cite this article as: Acharyya S: Activating mutations and senescence secretome: new insights into HER2 activation, drug sensitivity and metastatic progression. Breast Cancer Research 2013, 15:309. 